\title{
OS TERMINAIS PORTUÁRIOS PRIVATIVOS NA LEI № 8.630/93
}

\author{
Carlos augusto da Silveira Lobo*
}

I - O regime anterior - Monopólio; II - Os terminais privativos no Decreto-Lei $n^{0} 5 / 66$; III - Duas aberturas para a iniciativa privada na Lei $n^{\circ}$ 8.630/93 - Área do porto organizado - $O$ direito de construir $e$ operar terminais portuários; IV - O regime dos terminais privativos na Lei $n^{2} 8.630 / 93$ - Classificação dos terminais portuários - Os terminais privativos não são concessionários nem permissionários de servicos públicos - Os terminais de uso público são subconcessionários de serviços públicos portuários; $\mathrm{V}$ - Visão geral dos contratos referentes aos terminais portuários previstos na Lei 8.630/93 - O contrato de arrendamento referente a terminal de uso público - $O$ Contrato de Arrendamento referente a terminal privativo - Contrato de adesão

\section{I - O regime anterior - Monopólio}

O primeiro esforço notável de sistematização da legislação portuária brasileira foi empreendido em 1934, sob os auspícios de José Américo, então Ministro de Viação e Obras Públicas.

Em junho daquele ano, foram publicados os Decretos $\mathrm{n}^{\mathrm{0}} \mathrm{s} 24.447,24.508$ e 24.511, que, em conjunto, estabeleceram - até quanto era possível à época - um sistema legal para disciplinar os portos brasileiros. Esse sistema, com algumas modificações, vigorou até o advento da Lei no 8.630 , de 25 de fevereiro de 1993.

O sistema legal de 1934 baseava-se na idéia de que, a cada porto organizado, correspondia um "hinterland", cabendo ao porto organizado o monopólio do embarque e desembarque das mercadorias provenientes do seu "hinterland" ou a eles destinadas. Nesse sentido, o artigo $2^{2}$ do Decreto $\mathrm{n}^{\mathrm{Q}} 24.511$ dispunha que, em princípio, todas as mercadorias provenientes do "hinterland" de um porto organizado, ou a ele destinadas, teriam obrigatoriamente de transitar pelas instalações desse porto. Foi, assim, o Brasil dividido segundo um critério assemelhado ao das capita-

* Advogado no Rio de Janeiro.

\begin{tabular}{lll}
\hline R. Dir. Adm., & Rio de Janeiro, 220: 19-34, & abr./jun. 2000 \\
\hline
\end{tabular}


nias hereditárias, cabendo a cada porto um "hinterland" constituído por uma parcela do litoral e sua projeção para o interior do País.

Esse monopólio comportava certas exceções, as quais foram previstas exaustivamente no Decreto $\mathrm{n}^{\circledR} 24.511$. Dentre essas exceções, destacava-se a permissão para a carga e descarga nos "ancoradouros de franquia", desde que autorizadas pela Alfândega ou Mesa de Rendas e fiscalizadas pelo porto organizado sob cuja jurisdição estivesse $o$ ancoradouro.

Interessante notar que o artigo $6^{\circ}$ do Decreto $n^{2} 24.511$ veio estabelecer que as mercadorias que, por conveniência dos respectivos donos, deixassem de ser movimentadas nas instalações do porto organizado, ficariam sujeitas ao pagamento de uma contribuição correspondente aos encargos de amortização do capital nelas não obstante investido. Nesses casos, dentre os quais se incluía expressamente a mercadoria movimentada nos ancoradouros de franquia, incidia a Tabela $\mathrm{N}$.

Essa exação foi assim denominada porque foi prevista na última tabela que compunha o modelo de tarifa portuária instituído pelo Decreto $n^{2} 24.508 / 34$. As tabelas designadas pelas letras, de $\mathrm{A}$ até $\mathrm{M}$, fixavam a remuneração das diversas modalidades de utilização das instalações e dos serviços propiciados pelos portos organizados. Tal remuneração deveria compor-se do custo, mais a margem de lucro da Administração do Porto, mais os encargos de amortização do capital investido. A Tabela $\mathrm{N}$ não devia incluir nem custo nem margem de lucro, mas apenas a componente relativa aos encargos de amortização das instalações do porto organizado, não utilizadas na movimentação portuária de uma mercadoria.

Entretanto, cabe desde logo ressaltar, embora incluída na tarifa, a contribuição prevista na Tabela $\mathrm{N}$ não constituía na verdade um preço público, pois não correspondia a serviços efetivamente prestados. Tratava-se de uma taxa, cobrada por conta de serviços presumidamente postos à disposição, ainda que não utilizados pelo contribuinte.

Em 1944, surgiu o Decreto-lei $n^{9} 6.640$, que abriu uma brecha no monopólio ao permitir a construção e a exploração de "instalações portuárias rudimentares" pelos Estados e Municípios. Tais instalações portuárias, que se destinavam primordialmente a prestar serviços ao público mediante tarifas aprovadas pelo Governo Federal ${ }^{1}$, podiam ser exploradas por particulares, caso o Estado e o Município pertinentes se desinteressassem de tal atividade. As instalações portuárias rudimentares ficavam sempre sujeitas ao Poder Federal, que se reservava competência exclusiva para autorizar a sua construção e operação. Tratava-se, portanto, de verdadeiros "miniportos", ou portos em embrião, com organização precária, destinados a suprir a ausência ou deficiência dos portos organizados.

O art. 10 do Decreto-lei $n^{2} 6.640 / 44$, em consonância com o dispositivo já citado do Decreto $\mathrm{n}^{\mathrm{0}} 24.511 / 34$, determinava que as mercadorias movimentadas em uma

1 Portanto, essas instalações portuárias rudimentares executavam serviços públicos delegados mediante permissão, no que diferiam dos portos organizados, que eram explorados mediante concessão. 
instalação rudimentar ficavam sujeitas ao pagamento da Tabela $\mathrm{N}$ em favor do porto organizado a cujo "hinterland" a instalação rudimentar servisse.

\section{II - Os terminais privativos no Decreto-Lei $n^{2} 5 / 66$}

O Governo Castelo Branco, na tentativa de desenvolver o sistema portuário do País, editou o Decreto-lei $n^{2} 5$, de 4 de abril de 1966, cujo artigo 26 inaugura a história oficial dos terminais privativos.

Fê-lo com muita simplicidade, aproveitando o instituto já existente das "instalações portuárias rudimentares”. $\mathrm{O}$ art. 26 do Decreto-lei $\mathrm{n}^{\mathrm{Q}} 5 / 66$ veio dispor que qualquer pessoa poderia ser autorizada a construir e operar as instalações portuárias a que se referia o Decreto-lei $n^{9} 6.640 / 44$, desde que exclusivamente destinadas a uso próprio.

Cumpre, entretanto, ressaltar uma diferença fundamental entre o terminal privativo do Decreto-lei ${ }^{\mathrm{e}}$ 5/66 e a instalação rudimentar do Decreto-lei $\mathrm{n}^{\mathfrak{2}}$ 6.640/44. O terminal privativo não podia absolutamente ser utilizado por terceiros, ao contrário das instalações rudimentares, que se destinavam a prestar um serviço público, ainda que em caráter precário, mediante permissão do Governo Federal. Como veremos adiante, a prestação de serviços públicos, delegados mediante concessão ou, permissão, é objeto de um regime jurídico próprio, que não se estende aos terminais privativos. Na verdade, um terminal privativo do Decreto-lei $\mathrm{n}^{\mathrm{Q}}$ 5/66 nada mais era do que um estabelecimento, ou parte de um estabelecimento de uma empresa industrial ou comercial, a ser utilizado exclusivamente na atividade industrial ou comercial dessa empresa.

Tal como as instalações portuárias rudimentares do Decreto-lei $n^{2} 6.640 / 44$, os terminais privativos ficaram também sujeitos ao pagamento da Tabela $\mathrm{N}$ em benefício do porto organizado em cujo "hinterland" se localizassem, incidindo ainda a Tabela A, no caso de o terminal privativo se situar dentro da Área de Administração do Porto ${ }^{2}$.

Pouco depois, o Decreto-lei $n^{0} 83 / 66$ veio disciplinar a incidência dessas duas exações portuárias sobre os terminais privativos e instalações rudimentares. Para esse efeito, deu novas definições para "hinterland" e Área de Administração do Porto, conceitos já existentes desde o Decreto $\mathrm{n}^{\circ} 24.511 / 34$, e criou a categoria "zona de jurisdição", para designar a parte do "hinterland" formada pelas faixas litorâneas contíguas ao porto e pela cidade em que se localizam o porto e as respectivas repartições aduaneiras. Alterando o Decreto-lei $n^{\circ} 5 / 66$, o Decreto-lei $n^{Q} 83 / 66$ estabeleceu que a Tabela $\mathrm{N}$ só incidiria se o terminal privativo se situasse na zona de jurisdição do porto organizado.

Mas a modificação de maior importância introduzida pelo Decreto-lei n ${ }^{2}$ 83/66 foi determinar que a Tabela $\mathrm{N}$ devida pelos terminais privativos deveria ser fixada

2 A Tabela A continha verdadeiros preços públicos e visava a remunerar a utilização das instalações do porto organizado em cuja área o terminal estivesse situado. 
consoante instrumento bilateral, levando em conta, além dos encargos de amortização do porto organizado respectivo, a economicidade do empreendimento ao qual pertencia o terminal, a competitividade internacional do produto a ser nele movimentado (nos casos de exportação) e os níveis de preço no mercado interno (nos casos de importação). Dessa modificação resultou que a Tabela $\mathrm{N}$ deixou de ter a natureza de taxa, pois o seu "quantum" passou a ser fixado por mútuo acordo. ${ }^{3}$

De se mencionar por fim que o Decreto-lei $\mathrm{n}^{9} 83 / 66$, ao se referir ao instrumento bilateral de fixação da Tabela $\mathrm{N}$, cometeu a impropriedade técnica de qualificá-lo como "contrato de concessão ou autorização para construção e exploração do terminal ou embarcadouro de uso privativo". Como vimos, os terminais privativos dependiam de autorização para serem construídos e operados, autorização essa a ser outorgada por ato unilateral da Administração Pública, no exercício de seu poder de polícia. Instrumento bilateral só teria razão lógica de existir entre a concessionária do porto e o titular do terminal para fixar o "quantum" da Tabela $\mathrm{N}$ e a sua forma de pagamento.

\section{III - Duas aberturas para a iniciativa privada na Lei $n^{2} 8.630 / 93$}

Estavam os portos organizados e os terminais privativos na situação que vem de ser descrita, quando entrou em vigor a Lei $\mathrm{n}^{2} 8.630$, de 25 de fevereiro de 1993, introduzindo substanciais alterações em todo a sistemática portuária brasileira.

Dentre essas inovações, ressaltamos duas, que rompem com o regime de monopólio até então vigente.

Em primeiro lugar, a Lei $\mathrm{n}^{2} 8.630 / 93$, restringiu o espaço físico em que se manifestam os privilégios dos portos organizados: acabou com os conceitos de "hinterland" e de "zona de jurisdição do porto", criando o novo conceito de "Área do Porto Organizado".

Em segundo lugar, abriu oportunidade para que a iniciativa privada, em paralelo à atuação dos portos organizados, possa implantar e explorar instalações portuárias dentro e fora das áreas definidas como Área do Porto Organizado. Dentre essas instalações portuárias, implantadas e exploradas pela iniciativa privada, destacam-se os terminais portuários, de uso público e privativos, que são objeto deste estudo.

\section{Área do porto organizado}

Do ponto de vista territorial, a Lei $\mathrm{n}^{\mathrm{Q}} 8.630 / 93$ adota um novo conceito: o de "Área do Porto Organizado", que sucede com modificações importantes o antigo conceito de "Área de Administração do Porto". O conceito é definido pelo inciso IV do artigo $1^{\mathbb{Q}}$ da Lei $\mathrm{n}^{\circ} 8.630 / 93$ nos seguintes termos:

3 Sendo a taxa um tributo, é de essência que a sua alíquota e base de cálculo sejam fixadas por lei (cf. Código Tributário Nacional, art. 97, IV). 
"Área do Porto Organizado: a compreendida pelas instalações portuárias, quais sejam, ancoradouros, docas, cais, pontes e piers de atracação e acostagem, terrenos, armazéns, edificações e vias de circulação interna, bem como pela infra-estrutura de proteção e acesso aquaviário ao porto tais como guiascorrentes, quebramares, eclusas, canais, bacias de evolução e áreas de fundeio que devam ser mantidas pela Administração do Porto".

A noção de Área do Porto Organizado é fundamental na Lei $n^{2} 8.630$, eis que delimita o âmbito em que se exercem as funções e a autoridade da Administração do Porto. Nesse sentido, ao elencar as atribuições da Administração do Porto, o § $1^{2}$ do art. 33 da Lei $n^{2} 8.630$ expressamente ressalta que tais atribuições se exercem "dentro dos limites da área do porto". Somente estão sujeitos aos ditames da Lei ${ }^{\circ}$ 8.630 , diz o artigo $2^{\mathfrak{Q}}$, a prestação de serviços por operadores portuários e a construção, conservação, reforma, ampliação, melhoramento e exploração de instalações portuárias "dentro dos limites da Área do Porto Organizado". A Administração do Porto só tem poderes para fixar e arrecadar tarifas dentro da Área do Porto.Organizado, assegura o inciso IV do art. 33. Só se credencia como Operador Portuário a pessoa jurídica pré-qualificada para execução de operação portuária "na Área do Porto Organizado", dispõe o inciso III do $\S 1^{\mathbb{Q}} \mathrm{do}$ art. $1^{\mathrm{\rho}}$. A exploração de instalação portuária de uso público, diz o $\S 3^{0}$ do artigo $4^{2}$, "fica restrita à Área do Porto Organizado". E assim por diante.

Em suma, a Área do Porto Organizado delimita o espaço físico dentro do qual devem ser prestados os serviços públicos de natureza portuária, objeto da concessão, ou seja, é na Área do Porto Organizado que a concessionária exerce os poderes e deveres concernentes à concessão. Desnecessário ressaltar que a delimitação dessa área tem natureza meramente administrativa, não criando em favor da União ou da concessionária qualquer sorte de direito real ou preferência para adquirir direitos reais. Nada impede que o domínio útil ou a posse de terrenos situados em uma Área do Porto Organizado pertençam a um particular, como, aliás a lei prevê expressamente.

A especificação e delimitação precisa da respectiva Área do Porto Organizado é cláusula básica e essencial de todo e qualquer contrato de concessão ou ato de instituição de porto organizado.

É importante notar que a limitação da Área do Porto Organizado, adotada pelo inciso IV do art. $1^{\circ}$ da Lei $\mathrm{n}^{\circ} 8.630$, cujo texto se reproduziu acima, é muito mais restrita do que a da Área de Administração do Porto definida na legislação anterior (artigo $3^{\circ}$ do Decreto-lei $\mathrm{n}^{\mathrm{9}}$ 83/66), pois não inclui: (a) as costas ou margens beneficiadas direta ou indiretamente por tal infra-estrutura $e(b)$ as costas ou margens atingidas pela navegação interna do porto.

Portanto, na vigência da Lei $\mathrm{n}^{9} 8.630$, a Área do Porto Organizado abrange apenas as instalações portuárias e a infra-estrutura de acesso e proteção do porto, não podendo estender-se pelas costas ou margens beneficiadas por tal infra-estrutura ou atingidas pela navegação interna do porto.

A Área do Porto Organizado foi delimitada, em relação a cada porto organizado do País, por portarias do Ministério dos Transportes, que não se atêm aos estritos 
termos do inciso IV do artigo $1^{9}$ da Lei $\mathrm{n}^{\circ} 8.630$ e estendem os limites da área a sítios afastados do local em que se encontram as instalações do porto e a infra-estrutura de proteção e acesso. Por força dessas portarias, a nosso ver ilegais, é possível que haja terminais de fato submetidos ao regime aplicável aos terminais localizados dentro de Área do Porto Organizado tal como delimitada pelo Ministério dos Transportes, mas que, por lei, deveriam sujeitar-se às normas aplicáveis aos terminais localizados fora de Área do Porto Organizado.

O conceito de Área do Porto Organizado é importantíssimo para os terminais, pois, como veremos, o regime a que estarão sujeitos será diferente conforme o terminal esteja localizado dentro ou fora de uma Área do Porto Organizado.

\section{$O$ direito de construir e operar terminais portuários}

Consoante a lei portuária em vigor, qualquer pessoa jurídica poderá construir e operar um terminal portuário privativo em terreno de seu domínio útil, seja ele localizado dentro ou fora de Área do Porto Organizado, desde que, demonstrando ter capacidade para fazê-lo, obtenha autorização do Ministério dos Transportes (Lei $\mathrm{n}^{0} 8.630 / 93$, art. $6^{\circ}$ ).

O interessado em construir e operar terminal, dentro de uma Área do Porto Organizado, em terreno do qual a concessionária do porto tenha o domínio útil ou a posse legítima, deverá requerer à Administração do Porto que proceda à competente licitação pública para o arrendamento do terreno. Da decisão da Administração do Porto que denegar a licitação pública, cabe recurso para o Conselho de Autoridade Portuária. Sendo mantida a decisão, cabe ainda recurso para o Ministério dos Transportes (cf. art. $5^{\circ}$ da Lei $\mathrm{n}^{\mathrm{Q}} 8.630 / 93$ )

Realizada a licitação pública na forma da Lei $n^{9} 8.666 / 93$, o adjudicatário celebrará com a concessionária do porto um contrato de arrendamento, com os requisitos do $\S 4^{9}$ do art. $4^{9}$ da Lei $\mathrm{n}^{\varrho} 8.630 / 93$, que será comentado mais adiante.

\section{IV - O regime dos terminais privativos na Lei $n^{Q} 8.630 / 93$}

A Lei $\mathrm{n}^{9} 8.630 / 93$ redesenhou por inteiro o regime jurídico dos terminais privativos, colocando-os no contexto do seu Capítulo II, que trata das instalações portuárias não pertencentes aos portos organizados.

$\mathrm{Na}$ vigência da Lei $n^{\circ} 8.630$, os terminais portuários privativos não mais são considerados exceções toleradas ao monopólio dos portos organizados. O artigo $4^{\circ}$ dispõe que a qualquer interessado fica assegurado o direito de construir e operar um terminal portuário privativo, observados os termos e condições da lei. Assim, os terminais portuários privativos ombreiam com os portos organizados na estrutura portuária brasileira.

De acordo com a Lei $n^{9} 8.630 / 93$, os terminais podem ser de uso público ou de uso privativo. Os terminais de uso privativo, por sua vez, podem ser subdivididos em terminais de uso exclusivo e terminais de uso misto. 
Os terminais privativos de uso exclusivo correspondem aos já existentes sob a égide do art. 26 do Decreto-lei $n^{\circ}$ 5/66: só podem movimentar carga própria do respectivo titular, sendo-lhes vedado carregar ou descarregar mercadorias de terceiros.

Os terminais privativos de uso misto, criados pela Lei $n^{9} 8.630 / 66$, podem utilizar sua capacidade ociosa para movimentar cargas de terceiros mediante contratos de Direito Privado, sem interferência do Poder Público (cf. $\S 2^{\circ}$ do art. $6^{\circ}$ ). Distinguem-se dos terminais de uso público e dos portos organizados, porque não prestam um serviço público delegado: não são concessionários nem permissionários de serviços públicos.

\section{Classificação dos Terminais Portuários}

\begin{tabular}{|c|c|}
\hline Terminais de uso público & \\
\hline & \\
\hline Terminais privativos: & De uso exclusivo \\
\hline & De uso misto \\
\hline
\end{tabular}

Os terminais de uso público só podem ser implantados em Área do Porto Organizado. Os terminais privativos de uso exclusivo ou de uso misto tanto podem ser instalados dentro de Área do Porto Organizado, como fora dela.

No caso de instalação dentro de Área do Porto Organizado, a lei prevê duas hipóteses: (1) a instalação se dá em terreno cujo domínio útil ou posse legítima pertence à concessionária do Porto ou (2) em terreno cujo domínio útil pertença ao particular interessado, embora localizado dentro da Área do Porto Organizado.

Na primeira hipótese, como vimos, qualquer interessado poderá requerer à Administração do Porto a abertura de licitação tendo por objetivo a celebração de um contrato de arrendamento de um terreno localizado na Área do Porto Organizado, para que, no imóvel arrendado; o vencedor da licitação construa as instalações de um terminal portuário ou reforme, amplie ou melhore instalações existentes, com o fim de explorá-las. O contrato de arrendamento deverá conter as cláusulas essenciais previstas no parágrafo $4^{2}$ do art. $4^{0}$ da Lei $n^{2} 8.630 / 93$. Dessa forma, a lei assegura que os terrenos não ocupados e mesmo as instalações existentes mas ociosas, compreendidas em Área do Porto Organizado, tenham aproveitamento econômico pela iniciativa privada

Na segunda hipótese, isto é, se o terreno estiver situado dentro da Área do Porto Organizado mas o seu domínio útil pertencer ao interessado, a construção e operação do terminal dependerá de autorização do Ministério dos Transportes, não se celebrando, obviamente, contrato de arrendamento. É razoável que o Ministério dos Transportes subordine a autorização (que, como adiante veremos, será formalizada mediante um contrato de adesão) a um acordo entre o titular do terminal e a concessionária do porto organizado, estabelecendo o "modus vivendi" entre o terminal e o porto e os critérios para a remuneração pelo uso, se houver, por parte do terminal de equipamentos, instalações e infra estrutura aquaviária do porto. 
Quanto aos terminais privativos situados fora da Área do Porto Organizado, a sua construção e operação dependerá de autorização do Ministério dos Transportes, a ser requerida pelo titular do domínio útil do terreno onde será construído o terminal. Não se reconhece qualquer direito legítimo da concessionária de porto mais próximo em relação ao terminal, exceto se os navios que o demandam ou dele partem se valerem da infra-estrutura aquaviária de proteção e acesso do porto organizado, caso em que cabe ao terminal remunerar os investimentos e gastos efetuados pela concessionária na construção e manutenção dessa infra estrutura, na proporção em que tais investimentos efetivamente beneficiarem o terminal.

Os terminais privativos não são concessionários nem permissionários de servicos públicos

Neste ponto, convém fixar um conceito, que nos será de muita utilidade: o fato de a construção e a operação de terminais privativos estarem sujeitas a prévia autorização do Governo Federal não significa que os terminais privativos prestem serviços públicos delegados. Como veremos adiante, só os terminais portuários de uso público exercem, por subdelegação, serviços públicos.

Em Direito Administrativo, a palavra "autorização" tem duplo sentido. O primeiro significado do termo "autorização" designa uma forma de delegação de serviços públicos ${ }^{4} \mathrm{O}$ outro sentido designa uma modalidade de exercício do poder de polícia, pela qual se submete ao "placet" prévio da Administração Pública o exercício de atividades especialmente referidas na lei.

Não é necessário ir longe para tornar nítida a distinção entre os dois sentidos do termo. Basta compulsar os artigos 21, XII, e 170 da Constituição. No artigo 21, XII, a Constituição emprega o termo no sentido de forma de delegação de serviço público, ao estabelecer que "compete à União Federal explorar diretamente ou mediante autorização, concessão ou permissão" os serviços que relaciona. Já no artigo 170, a mesma Constituição usa o termo "autorização" no sentido de ato de polícia administrativa, ao assegurar a todos "o livre exercício de qualquer atividade, independentemente de autorização de órgãos públicos, salvo nos casos previstos em lei".

Ninguém duvida, por exemplo, que uma empresa, que explora linhas de ônibus urbanos, recebe uma delegação de um serviço público mediante autorização, autorização essa que nada tem a ver com a autorização que o Banco Central outorga a uma empresa financeira para funcionar, na forma do artigo 18 da Lei $\mathrm{n}^{2} 4.595$.

$\mathrm{O}$ fato de $\mathrm{o}$ art. 4으. II, da Lei $\mathrm{n}^{9} 8.630 / 93$ subordinar os terminais privativos a autorização do Ministério competente não significa que se trata de serviço público ou de utilidade pública. O citado dispositivo ao aludir a " autorização", está-se

4 A doutrina e a legislação moderna preferem utilizar o termo "permissão" para designar a delegação de serviços públicos em caráter precário (aliás, hoje em dia, com a Lei n 8.987/95, não tão precário). Todavia, ainda se encontra nos textos o termo "autorização" no sentido de delegação de um serviço público em caráter precário. 
referindo à autorização de que trata o art. 170, parágrafo único da Constituição, termo este bem definido por Caio Tácito:

"A autorização é ato administrativo que corresponde ao exercício, pela Administração, do poder de polícia, mediante o qual e em função do interesse público, a autoridade faculta ao particular a prática de uma atividade que lhe é própria, embora diferida em sua eficácia.

A autorização não é ato atributivo do direito. Representa ato liberatório pelo qual a Administração permite que a potencialidade de um direito ou liberdade individual se torne concreta. A eficácia contida adquire plenitude, uma vez concedida a autorização.

A autorização, em suma, não cria direito novo. Antes liberta direito preexistente. O titular é legítimo senhor de um direito, mas não dispõe da faculdade de exercê-lo, até que seja autorizado." ${ }^{5}$

Ora, é claro que o direito do titular do domínio útil de um imóvel propício, de nele construir e operar um terminal portuário, preexiste à autorização, embora esse direito só possa ser exercido após devidamente autorizado. A autorização apenas liberta o exercício do direito preexistente, sem alterar sua natureza. Quando se trata de serviço público, o direito preexistente é do Estado e só pelo Estado pode ser exercido, seja diretamente, seja mediante delegação a um particular. Se o Estado opta por delegar a execução do serviço, a delegação investe o delegado em um direito novo, que ele não tinha antes do ato da delegação. Esse direito novo, por sua própria natureza, se submete a um regime de Direito Público.

Portanto, fique bem claro que não há delegação de serviço público nos terminais privativos. Há autorização, relacionada com o exercício do poder de polícia.

O conceito de serviço público delegado tem como elementos fundamentais:

a) o objetivo primordial de satisfazer necessidades essenciais ou secundárias da coletividade, que o Poder Público julga de sua obrigação prover, seja diretamente, seja delegando a execução do serviço a particulares;

b) a submissão das relações jurídicas pertinentes ao serviço a regras exorbitantes do Direito Privado e peculiares ao Direito Público;

c) o direito de qualquer interessado de utilizar-se do serviço, em igualdade de condições com os demais usuários;

d) a obrigação de o prestador de um serviço público colocar o serviço à disposição dos interessados de forma regular e sem solução de continuidade;

e) a remuneração pelo serviço mediante tarifas publicadas, estabelecidas pelo Poder Público;

f) a fiscalização da qualidade e a regularidade do serviço pelo Poder Público delegante, havendo delegação.

Nenhum destes elementos está presente nas atividades dos terminais portuários privativos. Quando se trata de terminais de uso exclusivo, não há serviço prestado, 
pois é o próprio titular do terminal quem o utiliza com exclusividade. Quando se trata de terminais de uso misto, a própria lei, no $\S 2^{\circ}$ do artigo $6^{\circ}$ se encarrega de esclarecer que as relações entre o titular do terminal e os terceiros usuários são de Direito Privado, sem participação ou responsabilidade do poder público. ${ }^{6}$

Observe-se que o art. $4^{2}, \S 2^{2}$, II, "b" da Lei $n^{2} 8.630 / 93$ define o uso misto como a movimentação de carga própria e de terceiros, sendo certo que o termo terceiros do texto legal não significa o público em geral ou a coletividade. Por outro lado, esta modalidade de exploração não importa em impor ao titular do terminal privativo a obrigação de colocar à disposição do público ou de terceiros as instalações portuárias de modo a proporcionar-lhes a movimentação contínua, regular e cotidiana de suas cargas. Como se disse, o terminal privativo de uso misto movimenta carga de terceiros segundo a livre discrição do seu titular, mediante contratos privados.

O terminal privativo é um verdadeiro estabelecimento da empresa a que pertence e integra sua atividade industrial ou comercial, até porque a finalidade precípua do terminal é a movimentação da carga própria, relacionada com o empreendimento. A movimentação de carga de terceiros visa a ocupar a capacidade ociosa do terminal.

O titular do terminal privativo desfruta de ampla liberdade de contratar a movimentação de cargas de terceiros, na medida em que possa preencher a capacidade ociosa de suas instalações portuárias e na medida em que seus serviços satisfizerem às pretensões dos terceiros. Distingue-se, assim do serviço público portuário que, quando prestado por particulares, depende de delegação do poder público e se sujeita aos controles administrativos próprios.

\section{Os terminais de uso público são subconcessionários de serviços públicos portuários}

Os terminais de uso público prestam serviços públicos tal como acima definidos, ou seja:

a) o seu objetivo primordial é suplementar os portos organizados na satisfação das necessidades da coletividade, quanto a serviços portuários;

b) qualquer interessado tem o direito de utilizar-se do serviço, em igualdade de condições com os demais usuários;

c) o titular de terminal de uso público tem a obrigação de colocar o serviço à disposição dos interessados de forma regular e contínua, sem discriminar entre os usuários;

6 Ao discorrer com a habitual proficiência sobre o conceito de serviço público, Celso Antônio Bandeira de Mello ensina que "a característica essencial, nuclear, básica" do serviço público é a submissão "a um regime de Direito Público - portanto consagrador de prerrogativas de supremacia e de restrições especiais - instituído pelo Estado em favor dos interesses que tiver definido como próprios no sistema normativo". Portanto, é impossível vislumbrar serviço público quando a lei submete expressamente ao Direito Privado e exime o Poder Público de qualquer responsabilidade ou ingerência na prestação do serviço. Vide: Bandeira de Mello, Celso Antônio - Curso de Direito Administrativo, 12* ed., São Paulo, p. 575 e segs. especialmente a nota $\mathrm{n}^{2} 6$ na p.579. 
d) seus serviços devem ser remunerados mediante uma tarifa estabelecida pelo poder público, de aplicação geral;

e) seus serviços estão sujeitos a fiscalização pelo poder concedente

Por prestarem serviços públicos, suplementando os propiciados pelos portos organizados, os terminais de uso público só podem instalar-se em Área do Porto Organizado, segundo dispõe o $\S 3^{\circ}$ do art. $4^{\circ}$ da Lei $n^{\circ} 8.630 / 93$, pois os terminais de uso público devem necessariamente integrar-se no espaço em que os serviços públicos portuários são oferecidos ao público.

Em nosso modo de ver, os terminais de uso público se enquadram na figura da subconcessão, prevista no artigo 26 da Lei $n^{2} 8.987 / 95$ (Lei de Concessões de Serviços Públicos).

\section{$\mathrm{V}$ - Visão geral dos contratos referentes aos terminais portuários previstos na Lei $8.630 / 93$}

Como vimos, a Lei $\mathbf{n}^{\circ}$ 8.630/93 prevê duas espécies de contratos, que denomina, respectivamente, contrato de arrendamento e contrato de adesão. Como veremos, as duas denominações são infelizes.

\section{Espécies de contratos}

\begin{tabular}{|l|l|}
\hline $\begin{array}{l}\text { Contrato de Arrendamento } \\
\text { (para terminais de uso público e privativos) }\end{array}$ & $\begin{array}{l}\text {-quando o terminal se localiza (i) dentro da Área do } \\
\text { Porto Organizado e (ii) em imóvel pertencente à } \\
\text { concessionária do porto }\end{array}$ \\
\hline $\begin{array}{l}\text { Contrato de Adesão } \\
\text { (somente para terminais privativos) }\end{array}$ & $\begin{array}{l}\text {-quando o terminal } \text { é implantado (i) dentro da Área } \\
\text { do Porıo Organizado e (ii) em imóvel pertencente ao } \\
\text { seu titular } \text {; ou }\end{array}$ \\
\hline $\begin{array}{l}\text { Contrato de Adesão } \\
\text { (somente para terminais privativos) }\end{array}$ & $\begin{array}{l}\text { quando o imovel é implantado fora da Área do Porto } \\
\text { Organizado }\end{array}$ \\
\hline
\end{tabular}

Ao disciplinar esses contratos, a Lei n $8.630 / 93$ cometeu o erro de adotar como modelo o contrato de arrendamento referente aos terminais de uso público, enumerar exaustivamente suas cláusulas essenciais e estender a lista de cláusulas essenciais, com a exceção de alguns pontos, às demais espécies de contratos.

Ora, esse método só pode ser adotado quando se trata de contratos do mesmo gênero. Todavia, como veremos, os contratos em questão não comungam da mesma natureza jurídica, tendo como único ponto de relação o fato de versarem sobre atividades portuárias.

Assim, o chamado contrato de arrendamento de terminal de uso público pouco tem a ver com o contrato de arrendamento de terminal de uso privativo, além da

7 Observe-se que a lei não contempla a hipótese da implantação de um terminal de uso público em imóvel pertencente ao seu titular, dentro da Área do Porto Organizado 
circunstância de serem ambos os terminais localizados em Área do Porto Organizado. Quando se trata de terminal de uso público, estamos diante de um fato primordial, que preside todas as relações do contrato: a delegação de um serviço público. Como vimos, esse contrato é muito mais uma subconcessão de serviço público do que um arrendamento.

É certo que a concessionária cede ao titular do terminal a posse direta do imóvel em que se localiza a instalação, mas não com o objetivo de simplesmente arrendá-la. A cessão do uso tem como objetivo principal ensejar que o arrendatário possa prestar serviços portuários ao público. Por se tratar de uma delegação de serviço público, além das cláusulas pertinentes à locação do imóvel, é essencial estipular cláusulas assecuratórias da boa prestação dos serviços, tais como as relativas à sua qualidade e continuidade, às tarifas aplicáveis, à especificação das instalações e equipamentos que deverão reverter à concessionária ao fim do contrato, aos deveres do titular do terminal perante os usuários etc.

Portanto, o titular de um terminal de uso público é antes de tudo um subconcessionário do porto organizado; apenas secundariamente figura como um arrendatário de imóvel localizado em Área do Porto Organizado.

Já no contrato de arrendamento referente a terminal privativo, implantado em imóvel pertencente à concessionária, localizado em Área do Porto Organizado, não há delegação de serviço público, pois, ainda que o terminal seja de uso misto, não há relação de Direito Público entre o titular do terminal e o terceiro usuário. Então estamos diante de um verdadeiro contrato de arrendamento, onde sobreleva a cessão de uso remunerada de um imóvel, para servir de estabelecimento da empresa do titular do terminal.

Se formos examinar os contratos de adesão referentes a terminais privativos instalados em imóvel cujo domínio útil pertença ao seu titular, ainda que localizado em Área do Porto Organizado, nada encontraremos quer em relação a prestação de um serviço público delegado, quer em relação a arrendamento.

Se formos, mais adiante, examinar os contratos de adesão referentes a terminais privativos localizados fora de Área do Porto Organizado, verificaremos que estamos muito distantes do contrato de arrendamento referente a terminal de uso público, pois, além de não estarem presentes quaisquer elementos de arrendamento e de subconcessão de serviço público, nem mesmo se apresenta a circunstância de fato de o terminal estar localizado em Área do Porto Organizado.

Outra infelicidade da Lei $\mathrm{n}^{0} 8.630 / 93$ foi denominar e regular como "contrato de adesão" o instrumento mediante o qual o Poder Público outorga a autorização para construir e operar um terminal privativo, na forma do inciso II do art. $4^{\mathrm{o}}$.

Supor que essa autorização decorra de um contrato não está em consonância com a Teoria Geral das Obrigações e a Teoria dos Atos Administrativos, como a doutrina reiteradamente vem apontando. Com efeito, a autorização é tipicamente um ato unilateral da Administração Pública. Basta a manifestação da autoridade competente, na forma da lei, para que todos os efeitos jurídicos concernentes à autorização sejam deflagrados, independentemente de manifestação da vontade do auto- 
rizado. Diferente, portanto, de um contrato, cuja essência é formar-se mediante o encontro de manifestações de vontades das partes. ${ }^{8}$

Dizer que se trata de um contrato de adesão não atenua a erronia, pois também nos contratos de adesão, a manifestação da vontade das partes é indispensável. Não se consuma o vínculo sem que a parte aderente manifeste a sua vontade de aderir. Acresce que o termo "contrato de adesão" constitui a base de uma doutrina de Direito Comercial e, em especial, do Direito do Consumidor, que formula regras jurídicas não aplicáveis ao Direito Administrativo. Assim, a adoção do termo "contrato de adesão" para qualificar o ato unilateral de que estamos tratando, e outras figuras do Direito Administrativo - como a permissão - é inteiramente imprópria. Nesse sentido, cabe citar a irrespondível crítica ao artigo 40 da Lei $\mathrm{n}^{0} 8.987 / 95$, formulada por Marçal Justen Filho, na sua obra sobre Concessões de Serviços Públicos. ${ }^{9}$

Feita as advertências supra, estamos em condições de examinar cada um dos contratos previstos na Lei $\mathrm{n}^{2} 8.630 / 93$.

\section{O contrato de arrendamento referente a terminal de uso público:}

As cláusulas essenciais do chamado Contrato de Arrendamento referente a terminal de uso público, estão enumeradas no $\S 4^{0}$ do art. $4^{2}$ da Lei $n^{\circ} 8.630 / 93$, como sendo as relativas:

"I - ao objeto, à área de prestação e ao prazo;

II - ao modo, forma e condições da exploração do serviço, com indicação, quando for o caso, de padrões de qualidade e de metas e prazos para o seu aperfeiçoamento;

III - aos critérios, indicadores, fórmulas e parâmetros definidores da qualidade do serviço;

IV - ao valor do contrato, nele compreendida a remuneração pelo uso da infra-estrutura a ser utilizada ou posta à disposição da referida instalação, inclusive a de proteção e acesso aquaviário;

$\mathrm{V}$ - à obrigação de execução das obras de construção, reforma, ampliação e

8 Mesmo os contratos chamados unilaterais (que não se confundem com os atos unilaterais) dependem da manifestação das vontades das partes, embora só criem obrigações para uma delas (ex: o contrato de doação). Nesses contratos, as obrigações que competem a uma das partes apenas, nascem do encontro das vontades de ambas as partes. Tomando o exemplo: não existe contrato de doação, nem obrigação de doar, enquanto o donatário não aceita a doação.

9 Justen Filho, Marçal - Concessões de Serviços Públicos, São Paulo 1997, pág. 85. O notável jurista admite a existência de uma relação contratual na permissão de serviço público, embora critique a denominação "contrato de adesão". Os fundamentos que levaram o autor a admitir a existência de um contrato na permissão de serviço público não militam em favor da existência de um contrato na autorização. Assim, na autorização, não há contrato e, muito menos, um contrato de adesão. 
melhoramento, com a fixação dos respectivos cronogramas de execução físico e financeiro;

$\mathrm{VI}$ - aos direitos e deveres dos usuários, com as obrigações correlatas do contrato e as sanções respectivas;

VII — à reversão de bens aplicados ao serviço;

aos direitos, garantias e obrigações do contratante e do contratado,

VIII - inclusive, quando for o caso, os relacionados com as previsíveis necessidades de futuras suplementações, alterações e expansões do serviço e conseqüente modernização, aperfeiçoamento e ampliação das instalações;

IX - à forma de fiscalização das instalações, dos equipamentos e dos métodos e práticas de execução dos serviços;

$\mathrm{X}$ - às garantias para adequada execução do contrato;

$\mathrm{XI}$ - ao início, término e, se for o caso, às condições de prorrogação do contrato, que poderá ser feita uma única vez, por prazo máximo igual ao originalmente contratado, desde que prevista no edital de licitação e que o prazo total, incluído o da prorrogação, não exceda a cinqüenta anos;

XII - à responsabilidade do titular da instalação portuária pela inexecução ou deficiente execução dos serviços;

XIII — às hipóteses de extinção do contrato;

XIV - à obrigatoriedade de prestação de informações de interesse da Administração do porto e das demais autoridades no Porto, inclusive as de interesse específico da Defesa Nacional, para efeitos de mobilização;

$\mathrm{XV}$ - à adoção e ao cumprimento das medidas necessárias à fiscalização aduaneira de mercadorias, veículos e pessoas;

XVI - ao acesso, pelas autoridades do porto, às instalações portuárias;

XVII - às penalidades contratuais e sua forma de aplicação;

XVIII - ao foro."

Das cláusulas acima enunciadas. Em nossa opinião, somente as referidas nos itens I, V, IX, XIII, XIV, XV, XVI, XVII e XVIII cabem em todos os contratos previstos na Lei $\mathrm{n}^{\circ} 8.630 / 93$.

Como os contratos de arrendamento têm sempre como objeto um terminal localizado em Área do Porto Organizado, entendemos serem também essenciais cláusulas submetendo o funcionamento do terminal às nossas gerais de funcionamento do porto organizado, no qual o terminal estará fisicamente inserido.

\section{$O$ contrato de arrendamento referente a terminal privativo}

Este sim, é um verdadeiro Contrato de Arrendamento, pois, no caso em que se aplica, não há delegação ou subdelegação de serviço público. Meramente a concessionária do porto organizado loca um imóvel do qual tem o domínio útil para que ali se implante um terminal privativo. Já vimos que, mesmo quando se trata de terminal privativo de uso misto, a carga de terceiros é movimentada consoante relações de Direito Privado, sem interferência do Poder Público. 
Não nos parece em paz com a lógica e o bom senso a disposição do $\S 5^{0}$ do artigo $4^{\circ}$ da Lei $n^{\circ} 8.630 / 93$, que manda constar desse contrato todas as cláusulas enunciadas no $\S 4^{\circ}$ do art. $4^{\circ}$, com exceção apenas da referida no inciso VI. Se não cabe nesse contrato cláusula referente aos direitos e deveres dos usuários é porque se reconhece que não existe no caso prestação de serviço público. Se não há serviço público, também não cabem neste contrato as cláusulas referidas no inciso II, III e VIII, que versam sobre o modo e condições de exploração do serviço, indicação de padrões de qualidade do serviço, futuras alterações e expansões do serviço.

A cláusula referida no inciso XII, só teria cabimento para ressaltar que ao Poder Público não cabe qualquer responsabilidade pela má execução dos serviços contratados com terceiros, no caso de terminais de uso misto, responsabilidade essa que compete exclusivamente ao titular do terminal, tal como previsto no $\S 2^{\circ}$ do art. $6^{\circ}$ da lei.

Não obstante se tratar de um contrato de arrendamento típico, consideramos cabíveis as cláusulas referidas nos itens V, VII e IX, pois dizem respeito à obrigação de o arrendatário construir no imóvel arrendado as instalações e equipamentos de um terminal portuário e usá-las de forma apropriada, para que revertam ao porto organizado ao fim do arrendamento.

São, também cabíveis nesse tipo de contrato de arrendamento as cláusulas referidas nos itens I, IV, V, VII, IX, X, XI, XII, XIV, XV, XVI, XVII, e XVIII, assim como outras cláusulas, não previstas na lei, referentes à submissão do terminal aos regulamentos, regimentos internos, e normas gerais de funcionamento do porto organizado em cuja área se localiza.

\section{Contrato de adesão}

Como vimos, o contrato de adesão cabe nos casos em que o terminal se localiza em imóvel não pertencente à concessionária do porto, esteja esse imóvel situado dentro da Área do Porto Organizado ou fora dela.

Em tais casos a Lei prevê que a construção e operação do terminal depende de autorização do Poder Público e já vimos que essa autorização nada tem a ver com delegação de um serviço público, pois se trata de exercício do poder de polícia da Administração Pública, sob a égide do parágrafo único do artigo 170 da Constituição Federal.

Assim, o chamado contrato de adesão, no caso, formaliza a autorização do Poder Público, para que o interessado implante um terminal portuário em terreno de seu particular domínio (domínio útil, por se tratar de terreno de marinha). Ou seja: nesse caso, o terminal é um estabelecimento da empresa do titular, destinado a movimentar cargas próprias ou de terceiros, segundo um regime de Direito Privado.

$O \$^{2}$ do artigo $6^{\circ}$ da Lei $n^{\ell} 8.630 / 93$ dispõe que os contratos de adesão conterão as cláusulas referidas nos incisos I, II, III, V, VII, VIII, IX, X, XI, XII, XIV XV, XVI, XVII e XVIII do $\S 4^{9}$ do art. $4^{\circ}$ acima reproduzidos. Ou seja, segundo a lei, os contratos de adesão devem conter todas as cláusulas essenciais do contrato de 
arrendamento aplicável a terminais de uso público, menos as referentes aos incisos IV, VI e XIII.

Ora, já vimos que, por não se tratar de serviço público delegado, não tem cabimento a inserção das cláusulas referidas nos inciso II, III e VIII. Se a própria lei, no $\S 2^{\circ}$ do artigo $6^{\circ}$, dispõe que as relações entre o terminal privativo e os terceiros, que eventualmente os utilizam, serão regidas exclusivamente pelo Direito Privado, sem participação ou responsabilidade do Poder Público, não há como estabelecer no contrato normas desse teor.

A cláusula do inciso VII, sobre a reversão dos bens, justifica-se nos contratos de arrendamento, porquanto os investimentos efetuados pelo titular são supostamente amortizados no prazo contratual, seja mediante a inclusão da quota de amortização na tarifa - no caso de arrendamento/subconcessão - , seja mediante o abatimento no aluguel que justifica a reversão das benfeitorias nos verdadeiros contratos de arrendamento. Quando se trata de terminal objeto de contrato de adesão, por situar-se em terreno do domínio do titular, não há como estabelecer a reversão dos bens. Se o Poder Público julgar de interesse apropriar-se dos bens integrantes do terminal, por serem de utilidade pública, pode expropriá-los mediante prévia e justa indenização em dinheiro, como poderá fazê-lo em relação a qualquer bem do domínio privado.

Absurda nos parece ser, também, a submissão da autorização ao prazo máximo, inclusive prorrogações, de cinqüenta anos. Que fazer com as construções, instalações e equipamentos do terminal ao término do prazo? Se estiver localizado dentro da Área do Porto Organizado, a concessionária ou o poder concedente terão de pagar ao terminal a justa indenização, compreendendo o valor do domínio útil do terreno e as construções, instalações e equipamentos nele existentes, caso tenham interesse em operar o terminal. Caso não tenham interesse, todos esses bens serão sucateados? E quando se tratar de terminal localizado fora da Área do Porto Organizado? Em tais casos é de todo provável que o terminal estará umbilicalmente ligado às demais instalações da empresa, não havendo interesse em explorá-lo por parte da concessionária do porto ou por parte de outro particular. $O$ decurso do prazo fatal acarretará o abandono do terminal, ainda que a empresa titular tenha condições de continuar a utilizá-lo em seu negócio? 